\title{
SUBJECTIVE ESTIMATION OF THE QUALITY OF LIFE IN RELATION TO NEUROTICISM
}

\author{
Jasminka BOBIĆ \\ Institute for Medical Research and Occupational Health, Zagreb, Croatia \\ Received in July 2011 \\ CrossChecked in January 2012 \\ Accepted in March 2012
}

\begin{abstract}
It is generally agreed that personality variables have a relatively consistent influence on the subjective estimation of different situations in everyday life and the way people react to them. The aim of this review was to summarise our previously published findings on the relationship between subjective estimation of one's quality of life and the personality trait neuroticism-emotional stability. We used the WHO Quality of Life - BREF or SF-36 questionnaires for the assessment of the quality of life, Cornell Index for the assessment of neuroticism, and The Social Readjustment Rating Scale for the evaluation of common stressors. Our results have shown that more emotionally stable participants (lower neuroticism) perceive their life better in quality and are more satisfied with their work environment. In addition, our results support the findings from other studies that women have higher neuroticism and lower quality of life scores than men.
\end{abstract}

KEY WORDS: Cornell Index, emotional stability, neuroticism, quality of life, SF-36 WHOQOL-BREF

The World Health Organization defines the quality of life as "an individuals' perceptions of their position in life in the context of the culture and value systems in which they live and in relation to their goals, expectations, standards and concerns" (1). This wide concept includes a person's physical and psychological state as well as his or her social relationships, personal beliefs, and the degree of independence, all of which are rooted in a cultural, social, and environmental framework.

In a few of our recent studies we aimed to objectify the relationship between some personality traits and the estimation of one's quality of life, beside some other goals that are not the subject of this review. This review will summarise and discuss our published results that are based on correlations found between the subjective estimation of the quality of life and the personality variable neuroticism-emotional stability.
Individuals' perception of their own quality of life does not reflect the objective condition in terms of health status, mental state, social or financial position, but is rather a result of a person's characteristic pattern of behaviour that is usually strongly influenced by personality. As personality traits are stable, behavioural patterns and hence individual perception do not change much even in very different life situations. Personality traits may help to understand the way people see themselves and other people, the way they interpret occurrences in the environment, and the way they react emotionally to different situations. In a broad quality of life study, Wrosch and Scheier (2) stressed the importance of personality factors in the sense that "personality factors can impact on the way in which people approach life circumstances or on the kinds of outcomes people receive, which in turn can impact favourably or unfavourably on quality of life". 


\section{METHODS}

Since our results have been obtained using the following methods they will be presented in more detail. WHO Quality of Life-BREF (WHOQOLBREF)(1) instrument has been designed to assess subjective evaluation of quality of life in a variety of situations and population groups across cultures. It is a shorter version of the original WHOQOL-100 instrument and comprises 26 items which measure four broad domains: Physical health - refers to unpleasant physical sensations and discomfort, the level of energy and fatigue, and the quality of sleep and rest; Psychological health-examines how much a person experiences positive feelings (contentment, peace, happiness, hopefulness), negative feelings (gilt, sadness, nervousness, anxiety lack of pleasure in life), explores ones judgment of cognitive functions (learning, memory, concentration, attention, problem solving), examines self-esteem, persons body image, and personal beliefs; Social relationships - covers personal relationships and a broad concept of social support; and Environment - examines one's feeling of physical safety and security, home environment, financial resources, quality of health and social care, opportunities, and desire to learn and to participate in leisure, examines the persons view of his or her environment (noise, pollution), and the view of transport availability. According to Skevington et al. (3) psychometric properties of the WHOQOL-BREF instrument obtained from a survey carried out in 23 countries are in the range from good to excellent. The Croatian version of this instrument has shown high internal consistency as well as test-retest stability (4).

The Cornell Index (CI) is a self-administered true/false measure of personality traits that consists of 100 questions covering 12 psychological characteristics: hypersensitivity, phobia, anxiety, depressiveness, cardiovascular conversions, inhibitory conversions, gastric conversions, hypochondria, obsessive-compulsive tendencies, impulsive tendencies, aggression, and psychopathic tendencies (5). In addition, items of high desirability and low endorsement, and high desirability and high endorsement are added. The overall sum indicates the position of a person on a continuum of the personality trait emotional stability - neuroticism. CI has proven itself as a useful tool in detecting personality characteristics in a variety of groups (6-9).
SF-36 Health Survey is a multi-purpose questionnaire that contains 36 items, assessing subjective health through eight different health indicators/domains: physical functioning, rolephysical (referring to the limitations due to physical health problems), bodily pain, general health, vitality, social functioning, role-emotional (referring to limitations due to emotional problems), and mental health. Overall, it covers two general health concepts: physical and psychological. It was translated and validated throughout the world under the International Quality of Life Assessment Project (10). The standard Croatian version has demonstrated good psychometric properties and proved itself a valid and reliable tool to assess subjective health $(11,12)$.

The Social Readjustment Rating Scale (SRRS) is a standard measure for assessing a wide range of potential common stressors (13). It lists 43 either good or bad life events, each assigned with a value from 100 to 11 , reflecting the relative amount of stress. Since stress is cumulative, all scores are added and the sum represents the overall level of stress. Stress events range from death of spouse, divorce or death of close family member to change in residence or eating habits.

\section{RELATION BETWEEN NEUROTICISM AND THE ESTIMATION OF QUALITY OF LIFE}

Our surveys originally included 221 healthy administrative workers of both sexes (mean age $43.5 \pm 9.6$ years) from an insurance company, the national library, and national archive. We studied the association between neuroticism (CI), quality of life (WHOQOL-BREF), and the sick building syndrome (SBS), since SBS is regarded as a group of symptoms without specific aetiology. We found a statistically significant correlation between the personality dimension "emotional stability - neuroticism" measured on the Cornell Index and subjective evaluation of the quality of life using WHOQOLBREF (14). Substantial correlations between the sum result on CI and four domains on WHOQOL-BREF were as follows: psychological health $(-0.42)$; environment (-0.46); physical health (-0.49), and social relationships (-0.58). Other authors found a similar negative correlation between neuroticism and the quality of life, irrespective of what questionnaire 
or test was used for personality assessment (15-17). Persons who had higher emotional stability scores perceived their own lives better in quality, reported fewer symptoms related to SBS, and were more satisfied with work organisation. In other words, higher neuroticism scores on CI were associated with more frequent reporting of SBS symptoms. New reports using WHOQOL-BREF in a large elderly sample support our findings, stressing the beneficial role of emotional stability on the subjective estimation of quality of life (18).

On a subsample limited to women office workers $(\mathrm{N}=171)$ we determined skin and airway reactivity markers as well as indoor microclimate data that were compared with the information about SBS symptoms (19). These SBS symptoms are not specific, often without clear clinical signs, and are probably the result of a complex interaction of environmental, occupational, and psychological factors (20). The main scope was to examine the potential relationship between certain work-related health symptoms attributed to SBS and psychological, somatic and environmental factors in female office workers. Thus, we found that among the analysed environmental, somatic, and psychosocial factors only air conditioning and psychological factors were independent predictors of SBS symptoms. Furthermore, a separate analysis of psychological and somatic variables indicated only the level of neuroticism measured on CI, subjective estimates of the quality of life (WHOQOL-BREF, physical health), and stressful life events (SRRS) as predictors of general and local SBS symptoms (Pearson product-moment correlation coefficients: $\mathrm{r}=0.28 ;-0.28$, and 0.24 , respectively). Somatic variables did not predict reported symptoms of SBS. These results confirmed our assumption that personality traits would substantially affect the subjective assessment of the work environment in the way that emotionally less stable respondents would be less satisfied with it. These findings raise questions about how would different factors underlying work-related health symptoms affect the estimation of the quality of life in men office workers.

We were also interested in certain relations between psychological factors and allergic disorders, since a number of studies have underlined the interaction between biological, environmental, psychological, and social factors in an attempt to clarify allergic disease onsets and progressions as well as specific expression of symptoms (21-25). For this purpose we analysed a subsample of 145 out of 221 office workers to see if they had an atopy. Atopy is defined as a personal and/or familial tendency, usually in childhood or adolescence, to become sensitised and produce $\operatorname{IgE}$ antibodies in response to ordinary exposure to allergens. As a consequence, these persons can develop typical symptoms of asthma, rhinoconjunctivitis, or eczema. Therefore, the term atopy or atopic disease should be used when typical respiratory and/or skin symptoms are accompanied by elevated IgE levels and/or a positive skin prick test to common allergens (26). The subjects were divided into three groups according to atopic constitution and allergic symptoms: 1) those without signs and symptoms of atopy (57 subjects); 2) those with a positive skin prick test, but without relevant symptoms (28 subjects); and 3) those with a positive skin prick test and relevant atopic symptoms (60 subjects) (27). We did not find any significant association between four psychological factors measured on CI subscales (psychoticism, extraversion, neuroticim, and lie tendencies) and positive skin prick test, but, we did observe that women gave significantly lower estimates of their quality of life than men for the Environment domain on WHOQOL-BREF ( women $=5.46 \pm 0.02$; men $=4.75 \pm 0.03$ ), whether they had atopy or not. They also scored significantly higher on neuroticism expressed as the sum result on CI (women = $16.01 \pm 1.06$; men $=10.96 \pm 1.69)$ and anxiety on one of the CI subscales (women $=4.10 \pm 0.24$; men $=3.05 \pm 0.38$ ). Higher neuroticism scores in women than in men and lower subjective estimates of life quality are in accordance with earlier findings ( 3,28 , 29). Women also showed significantly higher stress levels on the Social Readjustment Scale (women = $214.19 \pm 13.25$; men $=160.53 \pm 20.76$ ). These gender differences may reflect the objective lower quality of life and more stressful life in women, but may also reflect the influence of personality on the way in which the quality of life and stressful life events are perceived. In other words, personality strongly influences the way in which a person approaches a variety of life situations and sees obstacles or opportunities.

Tesch-Römer et al. (30) presented results that were derived from comparative data sets involving 57 countries. These results show that gender differences in subjective estimation of well being are influenced by unequal access to relevant individual resources. They emphasised the importance of "macro-structural settings that describe the degree to which women are disadvantaged or excluded from societal resources 
and opportunity structures". The same pattern that access to important societal resources plays a beneficial role in quality of life was found in our study on the subjective perception of the quality of health in older population. The sample comprised 396 elderly subjects of both sexes, aged between 76 and 91 years, where we administered the SF-36 Health Survey (31, 32). Interestingly enough, our urban participants were more satisfied with their physical functioning $(\mathrm{F}=6.48$; $\mathrm{p}<0.01)$, vitality $(\mathrm{F}=6.55 ; \mathrm{p}<0.01)$, and mental health $(\mathrm{t}=2.7 ; \mathrm{p}<0.01)$ than the rural participants. Men and women differed in the estimation of general health; again men perceived their health better in quality $(\mathrm{F}=4.81 ; \mathrm{p}<0.05)$; vitality $(\mathrm{F}=6.41 ; \mathrm{p}<0.05)$, and mental health $(\mathrm{F}=4.81 ; \mathrm{p}<0.05)$. Although we did not query about personality traits in this study, these findings may help to better understand the complex concept of the quality of life. In a recent study by Oerlemans et al. (33), extraversion was defined as an important personality factor influencing activities that contribute to happiness and quality of life in older adults. Huang et al. (34) performed factor analysis for results obtained on a large sample of 11,440 Taiwanese subjects who answered the SF-36 and WHOQOLBREF questionnaires, in order to see if these two instruments measured the same constructs (34). They concluded that SF-36 measured health-related quality of life, while WHOQOL-BREF measured global health, including both health-related and non-health related quality of life. For this reason, the results obtained using these two instruments may be compared, but only to a limited extent.

Only a small number of studies have reported on the impact of neuroticism on the quality of life in healthy subjects while most refer to disease-specific subject groups. Dubayova et al. (35) studied Parkinson's disease patients and found a strong association between the quality of life and neuroticism as the second most important factor to the severity of the disease. They also found that only in men was extraversion significantly associated with higher scores on emotional well-being. In women, this association was inverted, that is, higher extraversion was associated with lower emotional well-being. A recent study by Van De Ven and Engels (36) showed that adolescents with asthma, high extraversion and low neuroticism scores reported better overall quality of life. In a large sample of psychiatric outpatients, Masthoff et al. (15) found that the quality of life correlated negatively with neuroticism and positively with extraversion. Den Oudsten et al. (37) noticed that high neuroticism, among other factors, predicted depressive symptoms in patients 12 months after surgical treatment of early-stage breast cancer. Van der Steeg et al. (38) also performed a longitudinal study in women with breast cancer, who were treated either with breast-conserving therapy or underwent mastectomy. Their results show that personality traits anxiety and neuroticism determined patients' poorer estimation of the quality of life after the treatment in both groups.

In sum, our studies are in accordance with other studies and demonstrate that individual differences in terms of personality characteristics, emotional stability-neuroticism in particular, play a significant role in perceiving one's own quality of life through different domains. The same may be extended to the perceived quality of the working environment. However, this conclusion that the sense of quality originates from within, that is, from personality as a stable and consistent trait, does not diminish the actual role of external situational influences. Another conclusion that is in accordance with other studies is that women show increased results on neuroticism measures as well as decreased results on the quality of life scales than men. This invites a broader investigation into the reasons that may underlie gender personality differences.

\section{Acknowledgement}

This research was supported by the Croatian Ministry of Science, Education and Sports (grant no. 022-0222411-2409).

\section{REFERENCES}

1. World Health Organization (WHO). WHOQOL, User Manual, Division of mental health and prevention of substance abuse. Geneva: WHO; 1998.

2. Wrosch C, Scheier MF. Personality and quality of life: the importance of optimism and goal adjustement. Qual Life Res 2003;12(Suppl 1):59-72.

3. Skevington SM, Lotfy M, O'Connell KA. The World Health Organization's WHOQOL-BREF quality of life assessment: psychometric properties and results of the international field trial. A report from the WHOQOL Group. Qual Life Res 2004:13:299-310

4. Radošević-Vidaček B, Macan J, Košćec A. Stres i alergija [Stress and allergy, in Croatian]. Arh Hig Rada Toksikol 2004;55:205-11

5. Weider A, Wolff HG, Brodman K, Mittelman B, Wechsler D. Priručnik za Cornell Index [Cornell Index Manual, in Croatian]. Jastrebarsko: Naklada Slap; 1997. 
6. Weider A, Brodman K, Mittlemann B, Wechsler D, Wolff HG. The Cornell Index. Psychosom Med 1946;8:411-3.

7. Avdibegović E, Sinanović O. Consequences of domestic violence on women's mental health in Bosnia and Herzegovina. Croatian Med J 2006;47:730-41.

8. Kulenović A, Buško V. Empirijska evaluacija dijagnostičke i pragmatičke upotrebljivosti pseudoupitnika Cornell index [Empirical evaluation of diagnostic and pragmatic utility of the Cornell index (pseudo) questionnaire, in Croatian] Suvremena Psihologija 1999;2:49-65.

9. Stevenson J, Meares R. Psychotherapy with borderline patients: II. A preliminary cost benefit study. Aust N Z J Psychiatry 1999;33:473-7.

10. Ware J E, Kosinski M, Bayliss MS, McHorney CA, Rogers WH, Raczek A. Comparison of methods for the scoring and statistical analysis of SF-36 health profile and summary measures: summary of results from the Medical Outcomes Study. Med Care 1995;33(Suppl 4):AS264-79.

11. Jureša V, Ivanković D, Vuletić G, Babić-Banaszak A, Srček I, Mastilica M, Budak A. The Croatian Health Survey - SF36: I. general quality of life. Coll Antropol 2000;24:69-78.

12. Maslić Seršić DM, Vuletić G. Psychometric evaluation and establishing norms of Croatian SF-36 Health Survey: Framework for subjective health research. Croat Med J 2006;47:95-102.

13. Holmes TH, Rahe RH. The social readjustment rating scale. J Psychosom Res 1967;11:213-8.

14. Bobić J, Gomzi M, Radošević-Vidaček B, Kanceljak-Macan B. Association of neuroticism with sick building syndrome, quality of life and psychomotor performance. Coll Antropol 2009;33:567-72.

15. Masthoff ED, Trompenaars FJ, Van Heck GL, Hodiamont PP, De Vries J. The relationship between dimensional personality models and quality of life in psychiatric outpatients. Psychiatry Res 2007;149:81-8.

16. Masthoff ED, Trompenaars FJ, Van Heck GL, Michielsen HJ, Hodiamont PP, De Vries J. Predictors of quality of life: a model based study. J Qual Life Res 2007;16:309-20.

17. Kováč T, Kuruc S. Quality of life: some personality aspects in relation to date measured by the WHOQOL-BREF (a Pilot Study). Studia Psychol 2002;44:235-42.

18. Brett CE, Gow AJ, Corley J, Pattie A, Starr JM, Deary IJ. Psychosocial factors and health as determinants of quality of life in community-dwelling older adults. Qual Life Res 2011:1-12. DOI: 10.1007/s11136-011-9951-2 Online First

19. Gomzi M, Bobić J, Radošević-Vidaček B, Macan J, Varnai VM, Milković-Kraus S, Kanceljak-Macan B. Sick Building Syndrome - psychological, somatic and environmental determinants. Arch Environ Occup Health 2007;62:14755.

20. Gomzi M, Bobić J. Sick building syndrome: Do we live and work in unhealthy environment? Period biol 2009;111:7984.

21. Baum A, Posluszny DM. Health psychology: Mapping biobehavioral contributions to health and illness. Ann Rev Psychol 1999;50:137-63.

22. Cohen S, Herbert TB. Health psychology: Psychological factors and physical disease from the perspective of human psychoneuroimmunology. Ann Rev Psychol 1996;47:11342.
23. Engel GL. The need for a new medical model: A challenge for biomedicine. Science 1977;196:129-36.

24. Kiecolt-Glaser JK, McGuire L, Robles TF, Glaser R. Emotions, morbidity, and mortality: New perspectives from psychoneuroimmunology. Ann Rev Psychol 2002;53:83107.

25. Lutgendorf SK, Costanzo ES. Psychoneuroimmunology and health psychology: an integrative model. Brain Behav Immun 2003;17:225-32.

26. Johansson SG, Bieber T, Dahl R, Friedmann PS, Lanier BQ, Lockey RF, Motala C, Ortega Martell JA, Platts-Mills TA, Ring J, Thien F, Van Cauwenberge P, Williams HC. Revised nomenclature for allergy for global use: Report of the Nomenclature Review Committee of the World Allergy Organization, October 2003. J Allergy Clin Immunol 2004;113:832-6.

27. Radošević-Vidaček B, Košćec A, Bakotić B, Macan J, Bobić $\mathrm{J}$. Is atopy related to neuroticism, stress and subjective quality of life? Arh Hig Rada Toksikol 2009;60:99-107.

28. Costa PT Jr., Terracciano A, McCrae RR. Gender differences in personality traits across cultures: robust and surprising findings. J Pers Soc Psychol 2001;81:322-31.

29. Feingold A. Gender differences in personality: a metaanalysis. Psychol Bull 1994;116:429-56.

30. Tesch-Rőmer C, Motel-Klingebiel A, Tomasik MJ. Gender differences in subjective well-being: Comparing societies with respect to gender equality. Soc Indic Res 2008;85:32949.

31. Pavlović M, Lauri Korajlija A, Šimić D, Bobić J, Čorović N. Percepcija zdravlja u pokretnih starijih osoba (segment studije o kroničnim bolestima u Hrvatskoj). Druš Istraž 2010;6:1079-92.

32. Ware JE, Kosinski MA, Gandek B. SF-36 Health Survey. Manual and Interpretation Guide. Lincoln: Quality Metric Incorporated; 2003.

33. Oerlemans GM, Bakker AB, Veenhoven R. Finding the key to happy aging: A day reconstruction study of happiness. J Gerontol B Psychol Sci Soc Sci 2011;66:66574.

34. Huang IC, Wu AW, Frangakis C. Do the SF-36 and WHOQOL-BREF measure the same constructs? Evidence from Taiwan population. Qual Life Res 2006;15:15-24.

35. Dubayova T, Nagyova I, Havlikova E, Rosenberger J, Gdovinova Z, Middel B, van Dijk JP, Groothoff JW. Neuroticism and extraversion in association with quality of life in patients with Parkinson's disease. Qual Life Res 2009;18:33-42.

36. Van De Ven MOM, Engels RCME. Quality of life of adolescents with asthma: The role of personality, coping strategies, and symptom reporting. J Psychosom Res 2011;7:166-73.

37. Den Oudsten BL, Van Heck GL, Van der Steeg AF, Roukema JA, De Vries J. Predictors of depressive symptoms 12 months after surgical treatment of early-stage breast cancer. Psychooncology 2009;18:1230-7.

38. Van der Steeg AF, De Vries J, Roukema JA. Anxious personality and breast cancer: possible negative impact on quality of life after breast-conserving therapy. World J Surg 2010;34:1453-60. 


\section{Sažetak}

SUBJEKTIVNA PROCJENA KVALITETE ŽIVOTA (WHOQOL-BREF) U ODNOSU NA NEUROTICIZAM (CORNELL INDEKS)

Općenito se smatra kako varijable ličnosti imaju važnu ulogu u relativno dosljednom utjecaju na subjektivnu procjenu različitih situacija u svakodnevnom životu, kao i na reakcije na te situacije. Cilj ovoga preglednog članka bio je objediniti naše objavljene rezultate o odnosu između subjektivne procjene kvalitete života i crte ličnosti neuroticizam - emocionalna stabilnost. Upotrijebljeni su WHOQOL-BREF ili SF-36 upitnici za procjenu kvalitete života, Cornell indeks za procjenu neuroticizma i The Social Readjustment Rating Scale za evaluaciju uobičajenih stresora. Dobiveni rezultati pokazali su kako osobe s izraženijom emocionalnom stabilnošću (manjim neuroticizmom) percipiraju svoj život kvalitetnijim te su zadovoljnije svojom radnom okolinom. Također je u skladu s drugim objavljenim studijama nađeno kako žene postižu više rezultate na skalama neuroticizma od muškaraca te niže rezultate na upitnicima kvalitete života.

KLJUČNE RIJEČI: Cornell indeks, emocionalna stabilnost, kvaliteta života, neuroticizam, SF-36, WHOQOL-BREF

\section{CORRESPONDING AUTHOR:}

\section{Jasminka Bobić}

Institute for Medical Research and Occupational Health

Ksaverska cesta 2, HR-10000 Zagreb, Croatia

E-mail:jbobic@imi.hr 